\title{
Muslim Women's Memoirs: Disclosing Violence or Reproducing Islamophobia?
}

\author{
Esmaeil Zeiny Jelodar ${ }^{1}$, Noraini Md. Yusof ${ }^{2} \&$ Ruzy Suliza Hashim ${ }^{2}$ \\ ${ }^{1}$ Center for Occidental Studies, Institute of Malaysian and International Studies (IKMAS), The National \\ University of Malaysia (UKM), Malaysia \\ ${ }^{2}$ School of Language Studies and Linguistics, Faculty of Social Sciences and Humanities, The National \\ University of Malaysia (UKM), Malaysia \\ Correspondence: Esmaeil Zeiny Jelodar, Center for Occidental Studies, Institute of Malaysian and International \\ Studies (IKMAS), The National University of Malaysia (UKM), 43600, Bangi, Selangor, Malaysia. E-mail: \\ mehdizeiny@gmail.com
}

Received: May 4, 2014 Accepted: May 19, 2014 Online Published: June 24, 2014

doi:10.5539/ass.v10n14p215 URL: http://dx.doi.org/10.5539/ass.v10n14p215

\begin{abstract}
As an upshot of 9/11, the literary market in the West saw a proliferation in writings by and about Muslim women. Many of these works are memoirs which focus on Islam, a patriarchal society, and the state's oppression on women. These Muslim women memoirists take the western readers into a journey of unseen and unheard events of their private lives which is apparently of great interest for the westerners. Some of these memoirs, which reveal the atrocities and hardships of living in a Muslim society under oppressive Islamic regimes, are fraught with stereotypes and generalizations. Utilizing Gillian Whitlock's theory of 'soft weapons' and studying the concept of Islam in Marjane Satrapi's Persepolis: The Story of a Childhood (2003), we argue that some of these Muslim life narratives are manipulated to meet political demands of the West through creating Islamophobia.
\end{abstract}

Keywords: Muslim memoirs, Islamophobia, imperialism, women, oppression

\section{Introduction}

Immediately after the tragic event of 9/11, the American media became fraught with different kinds of discourses portraying atrocities and hardships of the Middle Easterners in Islamic societies. As one of these media venues, the American literary markets witnessed a mass production of works engendered by Muslim women. Many of these works are memoirs and revolve around women, Islam, a patriarchal society, and the state's oppression. These authors recount painful and tortured experiences of their daily lives in the Middle East under the Islamic regimes. The authors of these memoirs provide insights into people of their country who have always been stereotyped. However, unfortunately, in some memoirs, these depictions are rarely truthful and realistic; they are, oftentimes, replete with stereotypes and generalizations. This unprecedented rise of memoir is a response to the western readers' curiosity about the Middle East. The rise of this genre could also be partly attributed to its promise to take the western readers into a journey of the writer's private life of unheard and unseen events which is of a great interest for western readers to explore. The western readers approach these Middle Eastern memoirs with certain sorts of expectations and desires: exoticism and gender oppression by the Islamic regimes; their expectancy is always fulfilled in the Muslim memoirs.

Disclosing gender oppression and exoticism of Islam in memoirs by and about Muslim women hinges on stereotypical depictions which have dominated Western discourses in representing the Middle East since the $18^{\text {th }}$ century. These clichés fall into 'coming-of-age memoirs,' 'honor-killing memoirs,' 'victim memoirs' and 'escapee memoirs.' The victim in all these memoirs is always the marginalized woman who is oppressed by the state's Islamic laws, beaten up by a male family member and killed to save face or breaks through a life of oppression and absconds from her country of origin to a secular heaven, the West. Islam in these texts is represented as a misogynist religion; hence, they create Islamophobia, an abhorrence of Islam and Muslims. There were few memoirs before 9/11 confronting the same issues but it is not much of a surprise that the post 9/11Muslim memoirs receive greater attention than their predecessors. Adam (2008) argues that 'infidel' (2007), the post 9/11 best-selling memoir of the pro-American, Ayaan Hirsi Ali, captivated more readers and news coverage than the American-ambivalent, pre-9/11 Egyptian author, Nawal El Saadawi, who has been dealing 
with the identical matters of child marriage, lapidation and women's right in her memoirs. Both authors reveal the violence against women in their country but the former receives much publicity in the West.

Writing a memoir is an effort by Muslim women to reclaim their identities as never in the past were they allowed publicizing their private lives. The social laws of patriarchal societies of the Middle East suggest that women must not reveal private aspects of their lives as private aspects should be kept within the domestic realm. It is praiseworthy that they defy patriarchy by the act of their writing and breaking the gender code. Conway (1998, $p$. 87) maintains that these memoirs should be read "as conscious acts of rebellion. Writing and publishing one's life history was moving beyond secret rebellion to announce one's reasons for breaking the gender code." Breaking the gender code is suggestive of the pleasant fact that men are no longer the monopolized owner of the memoir as a genre since women gained access to the restrictive territory. Muslim women's memoirs are not only to narrate the significant events of the authors' lives but they are also supposed to be an agent of change in the quality of the lives of people, especially women. Sadly, however, some of these Muslim women memoirs are manipulated to meet political demands of the West. The authors of these memoirs, who promise to dismantle the outdated orientalism, reiterate the stereotypes of women suffering behind the veil imposed by the oppressive Islamic regime. Their life stories are an amalgamation of twisted truths and fabricated events; at times, a memoir could be wholly concocted for political purposes of the West like the 'honor-killing' memoir of Norma Khouri's Forbidden Love (2003).

In 2004, Malcolm Knox, the Sydney Morning Herald reporter, unveiled Norma Khouri's bestseller Forbidden Love as a fraud. In less than two years, the life narrative was sold in great numbers: more than two hundred thousand copies in Australia, with forty thousand copies printed in the UK and fifty thousand copies printed in the United Sates (Pazargadi, 2010). Norma Khouri's fictional testimony is the hoax we had to have as the conditions and situations in her book are just right for a life narrative by and about Muslim and Arab woman to be 'ousted' by a fake "trader with tainted goods" (Whitlock, 2007, p. 106). Two texts and a writer with two very different identities committed this roguish act; however, there is only one single story to tell. In the United States, it is published as Honor Lost: Love and Death in Modern-Day Jordan (2003). The creamy white cover of the book can be seen as an access into forbidden spheres: veiled Muslim women, ancient debris in the background, and Arabic decorative stencil are all trademarks of associations amongst ethnicity, gender, and tradition that lead to the "veiled best-seller" (Whitlock, 2007, p. 106). Elsewhere, the same story appears with a different title: Forbidden Love is published in 2003. This book's cover had a black and glided color; however, it was jacketed with the same trademarks: veiled Muslim woman and Arabic ancient tradition. Random House, the publication group, ordered its removal when it was found to be a fraud and eventually rejected Norma Khouri as a reliable autobiographer (Whitlock, 2007, pp. 106-107).

In both of Norma's stories Honor Lost and Forbidden Love (2003), the very same story of punishment or terrible retribution is told. It focuses on honor killing; this is a "practice of retribution carried out by male family members when women bring dishonor to her family because of sexual indiscretions" (Whitlock, 2007, p. 107). Dalia and the narrator of the life narrative are close friends; both were born in 1970 and raised in Jabel Hussein district of Amman. Dalia is from a strict Muslim family and Norma is Catholic. They are running a unisex beauty parlor, opened in May 1990, which offers unique services in Amman: a salon catering for men and women. In March 1995, the girls' lives changed when a broad-shouldered handsome officer named Michael comes into the salon. Michael is an emotional, loving, and devoted man just unlike any Arab man that the girls have ever known or imagined. The doomed lovers, Dalia and Michael, and Norma jeopardize their lives on a perilous adventure "for simply a romance" (2003, p. 57). When Dalia's family discovered the affair, Dalia is stabbed in her own home by her brothers and father (Whitlock, 2007).

Losing Dalia in this way made vivid to me something I'd always known but had managed to ignore. I could no longer hide my true emotions and beliefs in the hope my silent cries would be heard. In memory of Dalia, I vowed to transform my silence into audible screams for justice and equal rights (Norma, 2003, p. 145).

Once Dalia was killed, Khouri claimed that she escaped from Jordan to Athens where she wrote the book and immigrated to Australia from there. Life narrative is assumed to be trustworthy and readers take the events in these life narratives as true and real incidents; unaware of the fact that these writers can easily distort realities into fiction. It is the same case for Norma before disclosure of the lies in her story. Norma Khouri keeps mentioning the indecent incidents that happened to her close friend and she saw with her own eyes in Jordan, but in fact, as Knox reveals, she left Jordan when she was three. All that hair salon and romantic affair was nothing but a figment of her imagination. This author is an opportunistic writer who invented terrors and reproduced Islamophobia through her 'honor-killing' memoir. Different critics revealed her lies one by one; and finally by 
August 2004 the different identities of the writer were laid bare. Rana Husseini, the Jordanian journalist and women's right activist, and Amal Al-Sabbagh, the director of the women's commission in Amman, have proven that Norma's story was untrue on multiple levels. They have found 73 errors related to the geography, location, culture and the discussed Islamic practices in the memoir (Pazargadi, 2010). Some critics believe that it is the timing of Norma's book that is of great significance: between the 9/11 attacks and the Iraq war, it was time for life narratives stressing the primitivism of Arab and Muslim societies (Whitlock, 2007, p. 109). Whitlock quotes Bolt (2004) asserting that all life narratives possess a scant distortion of truth, but Norma's "may be one of the many that are one big lie (2007, p. 110). Bolt (2004) believes that Norma had a usual strategy to achieve fame in a world longing for trendy sufferer and puts forward a statement that is worth considering:

Trade as a woman, if possible who is from some tribe or oppressed minority, and has survived the cruelty of whites/colonialists/right-wing thugs/rich guys. And if you aren't any of the above, then fake it. A scandal is a definitive event; it brings to light the social, political, and ethical investments of narrators, readers, and publishers in life narrative. A hoax brings autobiography out of the shadows and into the editorials, columns and opinion pieces of the Sunday tabloid. "Write a book that tells of your woe, or trades on it. Garnish it with New Age mysticism and ShowTime! Teary readers! Big sales! Just perfect for readers looking for the latest victims to weep over" (2007, p. 110).

Discussions about Norma's affair in the media raise the following questions: why can't publishers supervise the perimeters of life narratives to keep a credible product? "What are the rights of readers and responsibilities of publishers?" (Whitlock, 2007, p. 111). Whitlock (2007, p. 112) continues to argue the fact that autobiographies come into the West from the East - and distribute to form grassroots' opinion, consolidate clichés, and presents plot "custom-made for our times" shows their potentiality as propaganda. Arguments on legitimacy and authenticity are always of vital importance in the trajectory of minority life narratives and testimony should be always subjected to cross-examination. By recognizing the hoax or rogue as the 'dark side' of life narratives, Whitlock means to suggest that accusations of chic dissimulation and the questioning of legitimacy and trustworthiness always exist when a testimonial narrative is able to draw forth empathy and cognizance of human right issues (Whitlock, 2007, p. 112). Other critics such as Hamid Dabashi (2011) condemns these writings as providing justification for imperialism's 'war on terror' and reinforcing the hegemonic imperialism. Therefore, these memoirs can be 'soft weapons' in reproducing the Islamophobia as the narrators employ strategies to elicit sympathy from the western readers; hence, manufacturing the public's consent for the 'war on terror' project in Muslim countries. This sentiment can be confirmed by Whitlock's idea on memoirs:

[Memoirs] can personalize and humanize categories of people whose experiences are frequently unseen and unheard. To attend to a nauseated body at risk in Baghdad, or to hear a militant feminist body beneath a burka, to attach a face and recognize a refugee is to make powerful interventions in debates about social justice, sovereignty, and human rights. Life narratives can do these things. But it is a "soft" weapon because it is easily co-opted into propaganda. In modern democratic societies propaganda is frequently not the violent and coercive imposition of ideas but a careful manipulation of opinion and emotion in the public sphere and a management of information in the engineering of consent. Life narratives can be complicit in these processes $(2007$, p. 3$)$.

These memoirs flooded bookstores in the West; stretched across a wall of bookstore can be found several portrays of veiled Muslim women (Whitlock, 2007). This exotic exhibition of many copies of Muslim life narratives, all published in 2002-3 onwards, is absolutely haunting. Whitlock's question might be helpful here to mention: "How can a reader resist interpellation as a liberal Western consumer who desires to liberate and recognize" Muslim women "by lifting the burka and bringing" her "alongside us, barefaced in the West?" (2007, p. 47). Pulling the Western eyes behind the chador or under the burka is an effective rhetorical approach; it draws out both "sympathy and advocacy" that can be put to quite "various political and strategic uses" (Whitlock, 2007, p. 47). By portraying the unseen and unheard events of violence in their memoirs, Dabashi is of the idea that these memoirists play a crucial role in constructing a belief in the public that empires should be preserved and sustained "than in truly informing the public about the cultures they denigrate and dismiss" (2011, pp. 12-13). They fake authority when telling their white masters what they desire to hear, not what they need to know, and they are rewarded by being labeled "voices of dissent" by their white masters (Dabashi, 2011, p. 17). Dabashi (2011) argues that these authors play a key role in making the inversion of truth by fantasy appear rational. Their narratives became pervasive all over the Western market and this market was looking for the best and the smartest individuals with "a pigment to their complexion who could tell their tales with an accent to their English" (2011, p. 16). This was the time for the Muslim women authors to step forward to "oblige, accommodate and entertain" as American military was preparing to attack the Muslim world (2011, p.16). They 
promote the idea that imperialist's intervention is justified to fight Islamic terrorism saving Muslim women from their own men "white men saving brown women from brown men" (Spivak, 1988, p. 297).

Amongst these Muslim memoirs, Iranian women's memoirs have become increasingly popular and are well-received. This recent flourishing of memoirs by Iranian women occurred concurrently with the United States fixation on Iran as part of the Bush administration's project of 'Axis of Evil' and the interventions in Afghanistan and Iraq which took place under the justification of humanitarian act of saving people, especially women residing under the oppressive Islamic regime (Rastegar, 2006). This new wave of Iranian women memoirs includes Azar Nafisi's Reading Lolita in Tehran (2003), Marjane Satrapi's Persepolis: The Story of a Childhood (2003), Persepolis: The Story of a Return (2004), and Embroideries (2005), Roya Hakakian's Journey from the Land of No (2004), Azadeh Moaveni's Lipstick Jihad: A Memoir of Growing up Iranian in America and American in Iran (2005) and Marina Nemat's Prisoner of Tehran (2007) just to name a few. Almost all of these memoirs are the production of the author's imagination and reality. They are usually generalized, one-sided and out of context stories denigrating Islam. They depict the violence in the Islamic regime and the difficulties a woman goes through her daily life in Iran. In these memoirs, Islam is portrayed as denigrating women; thus, these texts can create good justification in maintaining imperialism through Islamophobia. One of the most successful memoirs of the recent wave is Satrapi's Persepolis: The Story of a Childhood (2003). It is Satrapi's highly acclaimed coming-of-age graphic memoir set in revolutionary Iran. Satrpi (2003) claims that she has written the memoir to dispel the stereotypes of the Orient and dismantle the outdated Orientalist myths.

\section{Persepolis and Its Reception in the West}

Currently residing in France, Marjane Satrapi, an Iranian born woman, is an illustrator, graphic novelist, and animated film director. She comes from a well-to-do and a 'highly intellectual and politically conscious' family and began to study in Europe when she was 14. Even in Iran, during her teen years, she attended the French school, the Lycee Française as she is from a privileged family. Persepolis: The Story of a Childhood (2003) opens when Satrapi is 10 years old and closes when she is 14 leaving for Austria. Her graphic memoir focuses on her life during her childhood which coincided with the end of the Shah's westernized regime, the beginning of the Iranian Revolution, and the commencement of the disastrous Iraq-Iran war (1980-1988). During this period, Satrapi gives a brief background of every momentous incident that happened in her county from her own perspective: from the time when the people of Iran decided to oust the Shah for his dictatorship, resisting against Ayatollah Khomeini's Veiling Act, and all the killings and bombardments during the Iraq-Iran war. There is also a secondary theme in her text: the influence of American and European popular culture and political imperialism on the Iranian people. Coming from a family with a long history of political involvement, Satrapi was introduced to thinkers like Marx at a very young age. She shows in her memoir how people became distraught at facing another dictatorial regime after toppling the Shah. She explains how an ocean of people eventually left the country due to war and the regime's strict rules, and so did she when she was only 14.

Persepolis I (2000) and Persepolis II (2001) were published by L'Association, a French publishing company which deals with comic books, in France. This publishing house is one of the most important publishers in France as it is the first one to publish authors such as Marjane Satrapi. Persepolis: The Story of a Childhood (2003), a compilation of Persepolis I (2000) and Persepolis II (2001) was first published in America by Pantheon, an imprint of Random House. Innovations in the domain of comic art and graphic narratives have encouraged a wide readership, and Satrpi's graphic narrative is certainly no exception. Satrapi's Persepolis: The Story of a Childhood, which is a combination of Persepolis $I$ and $I I$ in French, was first printed in France and was the recipient of many well-known awards. Satrapi's first volume of graphic memoir sold twenty thousand copies in a year and received the Angoulême Coup de Coeur Award and the Belgium Prix du Lion in in 2001. Satrapi has received the "Comic of the Year" prize in Germany in 2004. Her graphic memoir has been translated into more than 16 languages and a million people in 30 countries have read her graphic memoir. When it was published in America in 2003, critics compared it to Spiegelman's Maus (1991) and Joe Sacco's graphic reportage Palestine (1996) (Barzegar, 2012). Her graphic memoir was not only on bestseller lists but was also termed "phenomenon" by L' Association publisher Jean-Christophe Menu. All the comparisons and the connection with L' Association put Satrapi's work on the map and her work was given the status of "Commix"; in Spiegelman's term, it is a designation of multi-layered graphic narratives and accentuation of the amalgamation of private and public spheres vital to recreating the past (Spiegelman, 1988). The status of "BD culte" "(that is, a Bande Dessine e [BD] that is so popular the commix and artist have become a reference in the genre)" (Barzegar 2012, p. 12), was granted to Persepolis. The work faces a surprising reception in the West where it has been eulogized for its humanitarian efforts as one critic, Clarke (2003, p. 2), claims:

As a fifth-generation Canadian who has limited knowledge of the history or current situation in Iran, 
Satrapi's book did, indeed, show me a more accurate and more human picture of Iran and of Iranians. At a time when so much media attention is being given to Iran, this glimpse into life in Iran is very welcome and much needed.

Satrapi's graphic memoir is unique amongst Iranian women memoirists' memoirs as she used quite a new medium in her memoir. Satrapi's graphic narrative assists her to connect to a broader and more diverse readership than other Iranian memoirs. Having such a wide potential audience in the West, Satrapi's graphic memoir carries the possibility of being at the disposal of Western imperialism (Barzegar, 2012). Satrapi's graphic narrative's success can also be attributed to its topicality and the geopolitical climate of the time. The 9/11 event was a major cause of westerners' curiosity about Middle Easterners and their culture. This can be regarded as one element of Persepolis' huge popularity. Malek (2006, pp. 361-362) confirms that there is an eager market for these memoirs:

Amidst the popularity of memoirs in general, and women's memoirs, in particular, the post-9/11 atmosphere has created a level of curiosity towards Iran that, though it may have originated in the 1980s, was never satiated or answered publicly by Iranians themselves until recently. As Americans and others around the world seek insight into a country and a people that have been deemed "evil" and an imminent threat to Western society, Iranian exiles-and their children-have also begun to re-examine and work through their identities and histories. Many have found a voice in the memoir genre, letting go of what Farideh Goldin has termed an "imported taboo" of "speaking and writing candidly from our Iranian past."

Therefore, a part of its appeal can be seen in the Westerners' "greater interest in hearing from a member of the 'axis of evil', especially in an autobiographical form that promises to disclose the intimate secrets of an exotic other" (Naghibi \& O'Malley, 2005). Besides its topicality and geopolitical time of the book's publishing, there are two other issues for the memoir's huge success. One is its black and white seemingly simple drawings with which the memoirist tries to suggest that her childhood period was not carefree and simple unlike others. Although the black and white colors seem simple in drawings, they have deeper meaning (Quisocjo, 2008). Black and white images were utilized to show the vicissitudes of the time she was experiencing as a child during the times of change (Darznik, 2007). The second issue is using the childlike sketches. The graphic memoir might seem like children's stories because of the seemingly simple drawings. However, the book appealed more to adults than children. Darznik (2007) is of the idea that the amalgamation of these two elements was the reason for Satrapi's success. Therefore, the popularity and the commercial success of Satrapi's Persepolis: The Story of a Childhood can be attributed mostly to the geopolitical time of its publication. The fact that the graphic memoir is used as a history lesson reveals its immense popularity throughout the West. It should be emphasized again that the memoir's simple black and white artistry also helped the book to gain a great deal of popularity. On the graphic memoir's popularity, Constantino (2008, p. 433) quotes Whitlock questioning the political motives of this memoir and asks "one has to wonder, indeed, had [Persepolis] displayed anti-American or anti-Western sentiment, would it have been so widely circulated and therefore popular?"

\section{Persepolis: The Exoticization of Islam}

Satrapi depicts different aspects of Islam as a religion. As an Islamic practice, she begins with Ashura. As the tenth day of Muharram, Ashura and the ten days preceding it are occasions for mourning marking the martyrdom of Imam Hussein for Shia Muslims. On this event, Satrapi states that "hitting yourself is one of the country's rituals, during certain religious ceremonies, some people flagellated themselves brutally. Sometimes even with chains. It could go very far. Sometimes it was considered a macho thing" (2003, p. 96). This bizarre depiction implies that these Islamic practices and traditions seem like torment and are practiced to highlight machismo and have nothing to do with religious piety. Despite claiming that she wrote the memoir to dispel the Western perception about Iran and Iranian people, ironically enough she is bolstering the stereotype by depicting Islamic practices negatively. She depicts the ritual with exaggeration in a way that it appears strange to a Western reader. Satrapi is successful in showing the West the exotica they are looking for in Middle Eastern people with her depiction of Ashura. However, self-flagellation is not so alien in Christianity. Barzegar (2012) opines that once this ritual is put in its suitable religious context, it "can be compared to some Catholic religious practices" (2012, p. 42). She goes on to criticize Satrapi and argues that some practicing Catholics still use flagellation. She is of the idea that processions of flagellants are still favored in countries like Spain, Portugal, and Italy during Lent. Even more fanatical exercises of "mortification of the flesh" may be used to gain a modified state of consciousness. She continues giving similarities of this ritual with the Christians rituals practiced in the Philippines where people practice flagellation to show a devoted worship, they even go as far as self-crucifixion (Barzegar, 2012). 
The Western readers cannot help to face the twisted knowledge about this Islamic practice as it is depicted out of its contexts. By portraying the practice without its contextualization, Satrapi is, indeed, reinforcing such fabricated images to her readers in the West. These distorted images are taken as 'objective truth' by a Western reader unfamiliar with Iran. What enhances the harm of such fallacy is Satrapi's authority as native (Barzegar 2012). Another example that adds to the exotica of Islam in her graphic memoir is where the girls had to mourn the martyrs of the Iraq-Iran war twice a day. On these mourning sessions, Satrapi portrays a group of girl beating their breasts to respect the martyrs. She comments that "after a little while, no one took the torture sessions seriously anymore. As for me, I immediately started making fun of them" (2003, p. 97). By jeering at rituals that are considered sacred and venerable for most Iranians, Satrapi manages to stand apart from her cultural tradition and try to connect with outsiders or Westerners who do not comprehend these rituals. She makes the ideas of mourning outlandish in the minds of her Western readers. To continue the delegitimization of Islam, Satrapi starts to delegitimize Iran as Iran is an Islamic country. An instance of this can be seen at the eve of the anniversary of the Revolution when students are supposed to decorate the class; they do decorate the class but with toilet paper (2003, p. 97). Through Satrapi's protagonist, Marji, everything Islamic is disparaged to zero and is an icon for laughter. Commenting on their neighbor who had changed after the Islamic revolution, Marji says it is not just the dad and mom who have changed, "their son says he prays every day" (2003, p. 75). At this occasion, Satrapi's mother advises her to lie and tell everyone that she also says her prayer every day. The veil is associated with negativity and restriction throughout her memoir. Watching a public speech in T.V about excluding the material of "decadence" from the academic centers, Marjane's mother asserts that: "Soon they're actually going to force us to wear the veil and you, you'll have to trade your car for a camel. God, what a backward policy" (2003, p. 74). Marjane's mother gives a misinterpretation of the practice of veiling as she links it with unsophisticated camel riding culture. Instead of showing and representing the veil as a sign of honor and respect for those who practice it, Satrapi states that the practice of veiling is imposed to protect women from men who are "perverts" (2003, p. 74). In another instance, commenting on people's change after the revolution, Satrapi's mother mocks a woman who is wearing the chador. She asserts that "Last year she was wearing a miniskirt showing off her beefy thighs to the whole neighborhood. And now Madame is wearing a chador. It suits her better, I guess" (2003, p. 75). The woman changed to the chador although it was not mandatory yet. However, Satrapi's mother takes agency off from her by sneering at her for wearing a chador.

Because Marji and her mother are shown as having no amount of respect for the religion and scoff at everything Islamic, there is no space for leaving a good impression about Islam in Western readers. Muslim men and women, usually revolutionary guards, are portrayed as brutal and having a savage personality. The male and female Muslim characters are depicted the same in her drawings as always having a frowning expression: men have beard and women are covered head-to-toe. Moreover, they are depicted as nasty especially when they judge Marji and her mother for wearing lipstick, having no chador or even running in the streets. It is shown that men and women cannot dress the way they want to and they should dress according to Islamic rules. On having the same expression of Muslim male, Satrapi asserts that "Islam is more or less against shaving" (2003, p. 75). This identical depiction of Muslim men and women suggests to the Western readers that all Muslim look and behave the same which is in perfect opposition of her own claim to dispel the stereotypical perceptions of the Westerners' about Islam and Iran. In portraying Muslims, Satrapi adopts Western biases without even thinking that it may hurt the Iranian and Iran. The Western prejudices are adopted because she sees herself as different from other Iranian people. She, indeed, mimics the Western framework in portraying Islam and Muslims. By mimicking, she tries to align herself with the West. To complete her bizarre depiction of Muslim men, Satrapi portrays the Islamic leaders of her country brainwashing young people going to the Iraq war front. The prejudice of the West that the other is unsophisticated is extended via Satrapi's claim that the authorities encouraged young people to go to war in return for a key to heaven. Satrapi states that their family maid's son was given a key, a plastic one painted in gold, at school. The kids at school were told that "if they went to war and were lucky enough to die, this key would get them to heaven" (2003, p. 99). Her cousin, who is a soldier, asserts that (2003, p. 101):

It's awful. Every day I see busses full of kids arriving. They come from the poor areas, you can tell ... First they convince them that the afterlife is even better than Disneyland, and then they put them in a trance with all their songs ... its nuts! They hypnotize them and just toss them into battle. Absolute carnage. The key to paradise was for poor people. Thousands kids, promised a better life, exploded on the minefields with their keys around their necks.

The key to heaven is stereotypically portrayed to show the weirdness of Muslim men. Taking this depiction as true, Keshavarz (2007) believes that propaganda is a part and parcel of a war. It is typical that people go to war 
in return for a hero's reward. These kinds of rank and file can be seen everywhere, even outside Iran. However, as veterans of the Iran-Iraq war, Marandi and Pirnajmuddin (2009) refute Satrapi's claim about the key and argue that they would like evidence to support this claim as they have never seen anything like that during the war. They continue to criticize Satrapi for the absurdity of her claim by stating that one of the characteristics of Iranian native Orientalist discourse is the absurdity of such claims. They argue that " it seems that such people are so sure of the unexamined reception of anything even smacking of opposition to the Islamic revolution and Islam in general or any kind of hype about Iran that they do not deem it necessary to give at least a touch of credibility to their claims" $(2009$, p. 39). At the time when people are supposed to look up and respect each other's religion, Satrapi keeps denigrating Islam and practicing Muslims. Thus, with the distortions and generalizations, it could be argued that Satrapi's graphic memoir is written in favor of imperialism. It creates a justification for the Western intervention to save Iran, Iranian men and women from the savagery and backwardness of the authorities. She has succeeded in Othering and exoticizing Iran for her Western readers. The depictions become the stereotype that leaders in the Third World countries are despotic and authoritative.

Islam is shown as a backward religion in this memoir. A commonplace feature of these neo-Orientalist texts is the defamation of Islam and Islamic rituals. To portray the Muslim as the other, depicting religious fanaticism and extremism is the sine qua non in these texts (Dabashi, 2011). These cliché stereotypes are used to form opinion in the Western readers. The Western information about the East, as Said (1978) argues, is not produced from reality. Rather, it is generated from the presumed prototype that conceives all the "Eastern" societies identical to one another, and essentially dissimilar to "Western" societies. This preconceived knowledge establishes the East as the opposition of the West. Satrapi claims that by writing Persepolis, she challenges this preconceived perceptions of the East as backward people. She challenges this perception only through portraying a small liberal group which is her family. However, Barzegar (2012, p. 39) is of the idea that Satrapi bolsters the archetypal perspective of the Orient "with her depiction of Islamic practices by not grounding such images in the cultural and religious context of Iran." But Satrapi, in her introduction of the graphic memoir, insists that she wrote her memoir to erase the perceptions of the West's knowledge about Iran:

Since [the Islamic revolution], this old and great civilization has been discussed mostly in connection with fundamentalism, fanaticism, and terrorism. As an Iranian who lived more than half my life in Iran, I know that this image is far from the truth. This is why writing Persepolis was so important to me. I believe that an entire nation should not be judged by the wrongdoings of a few extremists.

The above-assertion is to be reputed as she is dramatizing the occurrences of three decades ago. Barzegar (2012) also refutes this and states that what happened thirty-two years back should not be an element of judging a whole nation. We concur with her belief that Satrapi's graphic memoir should not be taken as 'objective truth.' A great host of Western audience takes this memoir as an objective and historical fact overlooking the fact that memoir as a genre is subjective in its nature. The author is using an insider outsider perspective in writing the graphic memoir. Satrapi judges her people and culture from a Western gaze which in fact authenticates her observation as she is an Iranian and people will take her as a reliable author. The accentuated images of Islam and Islamic culture are represented in distorted form in texts like Satrapi's. The diverse depictions and explanations of Islamic extremism form the traits and characteristics of singular and socio-religious societies. In fact, these characteristics count for all the Muslim societies in the Western perceptions. These generalizations can be regarded as a problem of definition. However, as Hirschkind and Mahmood (2002, p. 349) argue these depictions are utilized to reinforce the political strategies:

That is, the reduction effected by terms like fundamentalism allows US public opinion in this moment to equate those who attacked New York and Washington with the Taliban regime in Afghanistan, with those Islamic schools that impart a strict interpretation of Islam, with Muslim preachers who criticize the US for its liberal social mores, with Arab families in Detroit that have daughters who wear headscarves. In so far as these different actors and institutions may be thought of as different faces of a global fundamentalism, now increasingly associated with terrorism, they may also be conceived of as legitimate targets, whether for intelligence gathering or for aerial bombing.

Sad to say, Iran and Iranians are associated with fundamentalism and terrorism (Clark, 2003) and texts like Satrapi's reinforce this perception of the West. Satrapi is to be criticized for her selective writing regarding the Islam and Islamic culture in Iran. As Dabashi (2011) argues 'selective writing' is one element with which a writer can be labeled 'native informer' as s/he is writing in favor of imperialism. Satrapi fails to mention a great number of poor Iranian people's perspectives about Islam and practice of Islam. She tries to connect herself with the Western audience by portraying a negative depiction of Islam and Muslims. Exotica is delivered to us via her depictions of Islamic practices and Muslims which are usually depicted as bizarre, backward, and hostile in this 
graphic memoir. It is assumed that Satrapi gives voice to the unheard marginal sect of the society as in these texts marginality is usually treated as center stage. The images of Muslims' brutality and the imposed Islamic rules on people might make us assume that the memoirist has given voice to the oppressed people in Iran. However, the three questions posed by Sardar should be kept in mind when confronting these texts: aren't these texts "a new twist to an old narrative? A new form of cultural exploitation? A new theory of imperialism?" (1998, p. 12). The analysis shows that the images of oppressed people are brought forth for exploitative reasons. Sardar's argument can be bolstered by Whitlock's (2007) assertion about contemporary autobiographies by Muslim women from the Middle East. She explains the fact that these memoirs have been accepted by neoliberal ideology displays the potency of autobiographies to impact the global audience. It is important to note that this paper has no intention whatsoever to reject all the ideas in Satrapi's graphic memoir. There are some positive aspects in the memoir such as criticizing the Islamic regime for its gender apartheid system. Some of the incidents which Satrapi portrays in her memoir did happen in Iran but the fact that she depicts them one-sided and out of contexts makes her memoir vulnerable to criticism. We feel empowered by her depiction of women's resistance to the forced veiling but feel alienated by her denigration of Islam and generalization of Muslims.

\section{Conclusion}

Satrapi's graphic memoir is being circulated as an exotic merchandize. It can be co-opted to reproduce the neo-liberal advocacy of globalization and imperialism when it concurrently appears to circulate disinterestedly. Islam, in this graphic memoir, is represented as the opposite of the Euro-American communities that identified themselves as "the West." Satrapi's graphic narrative and some other life narratives by women from the Middle East constantly create and recreate the imaginary divisions between "we" and "others." By condemning the Muslims and Muslim leaders continually, this graphic memoir, as a soft weapon, is helping Western imperialism by providing a one-sided negative depiction of an Islamic government. It also bolsters the stereotype of the West that the other is not capable of governing its country properly which tallies perfectly with the tenet of Colonialism that the white man is the savior of the other. Islam in this text is associated with brutality and exotica. There is a fundamental difference between good and evil in this graphic narrative. Good is usually portrayed as a non-Muslim culture and religion and bad or evil equals Islamic culture. Muslims in this graphic memoir are rendered as exotic and they are Othered as it is apparent in an influx of other Muslim women's memoirs which are being published thick and fast. These narratives point to legal concerns about the status and plight of women in Islamic countries and put that crisis squarely at the service of imperial warmongering. Islam in Satrapi's graphic memoir and texts like hers is belligerent and abusive of women; therefore, imperialist's intervention is justified to fight Islamic terrorism saving Muslim women from their own men.

\section{References}

Adams, L. (2008). Beyond the Burka. The New York Times. Retrieved from http://www.nytimes.com/2008/01/ 06/books/review/Adams-t.html?pagewanted $=$ all\&_r $=1 \&$

Ali, A. H. (2007). Infidel. Free Press Publication.

Barzegar, L. (2012). Persepolis \& Orientalism: A critique of the reception history of Satrapi's memoir. Colorado State University. Master thesis.

Bolt, A. (2004a). Presumed Guilty Again. Sunday Mail, 57.

Bolt, A. (2004b). Why We Love a Hard Luck Story. Sunday Mail, 33.

Clarke, C. (2003). Fuller Image. The Iranian.

Conway, J. K. (1998). When Memory Speaks: Exploring the Art of Autobiography. New York: Vintage Books.

Costantino, M. (2008). Marji: Popular Commix Heroine Breathing Life into the Writing of History. Canadian Review of American Studies, 38(3), 429-447. http://dx.doi.org/10.3138/cras.38.3.429

Dabashi, H. (2011). Brown Skin, White Mask. New York: Pluto Press.

Darznik, J. (2007). Writing outside the veil: Literature by women of the Iranian diaspora. Princeton. Dissertation.

Hakakian, R. (2004). Journey from the Land of No. Bantam, Auckland.

Hirschkind, C., \& Mahmood, S. (2002). Feminism, the Taliban, and Politics of Counter-Insurgency. Anthropological Quarterly, 75(2), 339-354. http://dx.doi.org/10.1353/anq.2002.0031

Keshavarz, F. (2007). Jasmine and Stars: Reading More than Lolita in Tehran. Chapel Hill: University of North Carolina Press.

Khouri, N. (2003a). Forbidden Love. A Harrowing True Story of Love and Revenge in Jordan. Sydney: 
Transworld Publishers.

Khouri, N. (2003b). Honor Lost: Love and Death in Modern-Day Jordan. New York: Atria.

Malek, A. (2006). Memoir as Iranian Exile Cultural Production: A Case Study of Marjane Satrapi’s Persepolis Series. Iranian Studies, 39(3), 353-380. http://dx.doi.org/10.1080/00210860600808201

Marandi, S. M., \& Pirnajmuddin, H. (2009). Constructing an Axis of Evil: Iranian Memoirs in the "Land of the Free". Ajiss, 26(2).

Moaveni, A. (2005). Lipstick Jihad: A Memoir of Growing up Iranian in America and American in Iran. Public Affairs Publication.

Nafisi, A. (2003). Reading Lolita in Tehran. New York. Random House.

Naghibi, N., \& O'Malley, A. (2005). Estranging the Familiar: "East" and "West" in Satrapi's Persepolis. ESC, 31(2-3), 223-248. http://dx.doi.org/10.1353/esc.2007.0026

Nemat, M. (2007). Prisoner of Tehran. Simon \& Schuster: New York.

Pazargadi, L. (2010). Marketing “Honor Killing” Memoirs: Confronting Western Depiction of Muslim Women. Thinking Gender Papers, UCLA Center for the Study of Women, UC Los Angeles.

Quisocjo. (2008). Marjane Satrapi, declaracions a Sies.tv. [Vedio File]. Retrieved from http://www.youtube.com/ watch? $\mathrm{v}=\mathrm{tdnDi5tj7Z4}$

Rastegar, M. (2006). Reading Nafisi in the West: Authenticity, Orientalism, and "Liberating" Iranian Women. Women's Studies Quarterly, 34(1\&2), 108-128.

Sacco, J. (1996). Palestine. Fantagraphics.

Said, E. (1978). Orientalism. New York: Random House, Inc.

Sardar, Z. (1998). Postmodernism and the Other: The New Imperialism of Western Culture. London :Pluto Press.

Satrapi, M. (2003). Persepolis: The Story of a Childhood. New York: Pantheon Books.

Satrapi, M. (2004). Persepolis: The Story of a Return. New York: Pantheon Books

Satrapi, M. (2005). Embroideries. New York: Pantheon

Spiegelman, A. (1986). Maus: My Father Bleeds History. New York: Pantheon.

Spiegelman, A. (1988). Commix: An Idiosyncratic Historical and Aesthetic Overview. Print, 42(7), 61-96.

Spivak, G. C. (1988). Can the Subaltern Speak? Marxism and the Interpretation of Culture, 58(1), 271-313.

Whitlock, G. (2007). Soft Weapons: Autobiography in Transit. Chicago, University of Chicago press. http://dx.doi.org/10.7208/chicago/9780226895277.001.0001

\section{Copyrights}

Copyright for this article is retained by the author(s), with first publication rights granted to the journal.

This is an open-access article distributed under the terms and conditions of the Creative Commons Attribution license (http://creativecommons.org/licenses/by/3.0/). 